\title{
Efficacy of disinfectants and brand reputation on bathing water quality improvement
}

\author{
I.T Tenebe ${ }^{\mathrm{a}, \mathrm{b}, *}$, C.C Nnaji ${ }^{\mathrm{c}, \mathrm{e}}$, P.C. Emenike ${ }^{\mathrm{d}}$, B.U. Ngene ${ }^{\mathrm{d}}$ \\ ${ }^{a}$ Ingram School of Engineering, Texas State University, San Marcos, TX United States \\ ${ }^{\mathrm{b}}$ Texas Commission of Environmental Quality, Critical Infrastructure Division, Austin, TX United States \\ ${ }^{c}$ Department of Civil Engineering, University of Nigeria, Nsukka, Enugu State Nigeria \\ ${ }^{\mathrm{d}}$ Department of Civil Engineering, Covenant University, Ota, Ogun State Nigeria \\ ${ }^{\mathrm{e}}$ Faculty of Engineering and Built Environment, University of Johannesburg, South Africa
}

A R T I C L E I N F O

\section{Keywords:}

Bathing water

Antibacterial

Bacteria

Disinfectant

Antiseptic

Pollution

\begin{abstract}
A B S T R A C T
This study evaluated the antibacterial efficacy of some disinfectants widely used in Nigeria in the elimination of common bacteria found in bathing water. Four (4) skin disinfectants Ivy, Dettol, Izal, and Septol, were added to sterile distilled water containing Escherichia coli (E. coli), Klebsiella spp. and Bacillus spp. which were isolated from a swimming pool. From a total of 288 samples, results revealed that all the antiseptic performed below par in destroying bacillus except for Ivy (41.67\%) and Dettol (12.50\%), which showed tenuous performance in this regard. Septol showed no significant difference in destroying bacteria with a higher number of CFU/100 mL eliminated irrespective of the contact time $(p=0.258)$. In contrast, Ivy showed high significant difference with bacteria destruction as contact time progressed $(p=0.011)$. The logistic regression model developed revealed that an increase in dosage promoted the removal of organisms while longer waiting times were only significant for Septol $(p=0.045)$ and Ivy $(p=0.002)$. Nagelkerke $\mathrm{R}^{2}$ model fitted properly for Izal and Septol with values of 0.97 and 0.786 . The findings of this study showed stark variance among the treatment capacities of these antiseptics. They provided sufficient knowledge in the selection of the available skin disinfectants in the market that are most likely to destroy bacteria in bathing water. Therefore, the inability of these products to correlate with their intended purpose leaves room for re-assessment by their producers and by relevant monitoring agencies in the country to meet the demands of a rapidly growing number of end-users in dire need for improved bathing water quality.
\end{abstract}

\section{Introduction}

Water is pertinent to daily lives; without it, accomplishing daily activities would be herculean (Tenebe et al., 2016). It required a good quality for healthy living, but when not available, it could result in water-related diseases (Palaniappan et al., 2010; Omole and Ndambuki, 2014). Besides this, it can also be a conduit for which microorganism such as bacteria, protozoa, and viruses find their way into the body leading to certain kinds of diseases (Coleman et al., 2013; Ali et al., 2017; Cui et al., 2017). According to Gupta and Vegelin (2016), about 25 percent of the world's population is without sufficient water. However, despite this contamination likelihood in the various sources reported, water treatment is a preferred option for reducing water stress. There are different sources in which water for several purposes can be obtained depending on usage. Emenike et al. (2017) revealed these sources of water in a typical community, which included rivers, rainwater, commercial, private, and piped public taps, among others. Water from these sources used for bathing, cleaning, cooking, drinking, and washing and are prone to contamination. The reason for this is that bacteria are ubiquitous in the atmosphere and are transported mainly through precipitation and surface run-off into underground tanks in areas were tap, or borehole water is challenging to drill due to the nature of basement rocks and the position of the water table.

Additionally, in areas where boreholes exist, the water quality may be compromised due to shallow wells or improper cased boreholes after drilling. Several studies have reported that these sources can be contaminated with bacteria (Ahmed et al., 2010; Mwabi et al. 2012; Abegunrin et al. 2014; Khan et al., 2017; Chubaka et al., 2018) thereby increasing the risk associated with its usage. Due to microbial contamination that is likely in these different water sources, various consumers patronize the use of antiseptic or disinfectant for their removal, primarily when used for bathing. Removal of organisms from bathing

\footnotetext{
* Corresponding author at: Ingram School of Engineering, Texas State University, San Marcos, TX United States.

E-mail address: itt1@txstate.edu (I.T. Tenebe).
} 
water will result in reduced health risk effects, which includes skin and wound infections (Okore et al., 2014). The use of antiseptic or disinfectant has shown to improve bathing water quality (Tenebe et al. 2019). Disinfectant usage reduces the effect of the microbial population in water by making them inactive or destroying them (Agunwamba et al., 2013; Vestby and Nesse, 2015). Alkolaibe et al. (2015) mentioned that disinfectants are effective by destroying the cells and target sites of these organisms even though some organisms may resurface after continuous disinfection. Different methods have been adopted in the literature to determine the strength or potency of these disinfectants on microorganisms. For example, Saha et al. (2009) reported the performance of some antiseptics and disinfectants on some pathogens using zone of inhibition as a method for assessment and has been used in the form of liquid or solid in some studies for these purposes as well (Riaz et al., 2009; Olowe et al., 2004; El-Mahmood and Doughari, 2009; Farzana et al., 2011). However, most of these studies used minimum inhibitory concentration (MIC) to determine the efficacies rather than conducting a time-kill experiment. This time-kill experiment will give some insight on their performance over a prolonged time rather instantaneous. The reason for this is that the active ingredients may deteriorate over time, reducing potency, which makes it unsuitable for bathing, which is the case in this study. With several antiseptic or disinfectants available in the market to the teeming population, there is a dearth of literature revealing the relative performance of these disinfectants towards the removal of predominant bacteria for better water quality (Tenebe et al. 2019). Therefore, it becomes expedient to investigate different antiseptic efficacies on different organisms as their performance varies (Russell, 1996; Saha et al., 2009). These organisms may either be gram + ve or gram -ve in nature, so having a product with a wide range of performance will be worth the cost. According to Tytler et al. (2006), gram -ve organisms are more predominant than its counterpart. As in bathing water, disinfectants are applied in a specific volume of water a couple of minutes before use to ensure the proper functioning of the product. To the best of our knowledge, very limited studies has reported the use of disinfectants and their effectiveness in combatting organisms in bathing water. According to Reichel et al. (2014), to achieve this, is it better to conduct this experiment in a suspension to investigate the strength of any disinfectant. Therefore, this study aims to investigate the performance of several disinfectants in the elimination of bacteria towards a safer bathing water quality and to determine the proper volume and the exposure time or duration required for optimum activity of these products using a time-kill experimental procedure.

\section{Materials and methods}

The prevalence of certain water-borne bacteria in the study location was identified by a microbial screening of water samples collected from a swimming pool in Covenant University in three separate $4 \mathrm{~L}$ sterilized containers. Water samples from the pool were inoculated on already prepared sterile nutrient agar plates and incubated at $37^{\circ} \mathrm{C}$ for $24 \mathrm{~h}$. Gram staining method was then applied to observe and separate bacterial colonies on the plates after $24 \mathrm{~h}$, and the organisms isolated were Klebsiella Spp., Escherichia coli (E.coli), and Bacillus spp. A focused grouped discussion was conducted within the Covenant University community, where samples were collected. The community has a population of over 10,000 people. Some of the participants were asked questions on common antiseptic used in their homes and the reason for their choices. Based on the outcome of this discussion, four (4) disinfectants, namely: Izal, Dettol, Septol, and Ivy, were selected to ascertain their potency on the isolates to identify their zone of Inhibition (ZOI). To determine the ZOI, Mueller Hinton Agar was prepared according to manufacturer's specification and autoclaved at $121{ }^{\circ} \mathrm{C}$ for $15 \mathrm{~min}$, after which the agar could cool to $40{ }^{\circ} \mathrm{C}$ and then dispensed into sterile Petridishes and allowed to solidify. A sterility test was carried out by leaving the already sterile plate in the incubator overnight to ascertain any possible contamination. Each prepared plate was seeded with bacterial isolates. A sterile $9 \mathrm{~mm}$ cork borer was used to bore a well on the already seeded plates, and $0.2 \mathrm{~mL}$ Izal was dispensed into the well and incubated at $37^{\circ} \mathrm{C}$ for $24 \mathrm{~h}$. The ZOI was recorded for each antiseptic measured in (mm). This process was repeated for all the other disinfectants under study. Erythromycin was used as the control against the antiseptic, and the diameter of the plate measured was $20 \mathrm{~mm}$. To ascertain the potency of the disinfectants on isolated microorganisms, 500 $\mathrm{mL}$ of sterile distilled water was dispensed into sterile conical flasks. To each conical flask, $0.4,0.8,1.2$, and $1.6 \mathrm{~mL}$ of Izal were dispensed using the pour plate method. The bacterial isolates were standardized to 0.5 McFarland standard, and $2 \mathrm{~mL}$ was added to each conical flask containing sterile distilled water and disinfectants. After five (5) minutes, $0.5 \mathrm{~mL}$ of the above mixture was drawn with a pipette and dispensed into a sterile Petri dish and mixed with warm $30^{\circ} \mathrm{C}$ nutrient agar which was swirled clockwise and anticlockwise then incubated at $37^{\circ} \mathrm{C}$ for 24 h. Total viable colonies obtained for each disinfectant was reported. This process was repeated after 10, 15, 30 and $60 \mathrm{~min}$ as well as for others

\subsection{Statistical test}

\subsubsection{Normality and chi-square test}

Statistical analysis was performed using Stata version 14.0 (StataCorp, Texas, USA) and SPSS Version 21. First and foremost, a normality and independence test was conducted. These tests represent an empirical distribution test function typically used to distinguish a cumulative distribution test function from the empirical distribution function of any data. In this study, it was used to determine the adequacy of the statistical test procedure to adopt for this study. The result from the statistical process revealed that the non-parametric statistical methods were suitable. The non-parametric two-sample Mann-Whitney $\mathrm{U}$ test (Wilcoxon rank-sum test) was used to determine the significant difference, if any, in the median of the categorized bacteria count (bacteria and no bacteria counts) using $95 \%$ confidence level. Paired $t$ test was used to compare the level of significance between the mean difference in the zone of inhibition (ZOI) for each antiseptic on the different bacteria while the Pearson's chi-square test was used to compare how bacteria count varied with the type of antiseptic used, contact time and dosage respectively

\subsubsection{Logit regression model}

This kind of model is developed to predict datasets with a binary response, which has a binomial distribution with a mean of 1 and a standard deviation of $\pi_{x}$ (Eq. 1). They vary from typical simple linear regression models whose responses require a continuous count, normally distributed with a mean value of $\mu_{x}$ and standard deviation of $\sigma^{2}$ (Eq. 2). On the flip side, they both share similarities in their parameter expression (Eqs. 3 and 4 ) i.e., having slope $\left(\beta_{1}\right)$ and intercept $\left(\beta_{0}\right)$. The binary regression model is expressed in terms of odds or odds ratios. This odd ratio is defined as (Montgomery et al., 2012)

$\mathrm{Y} \sim \mathrm{N}\left(\mu_{x}, \sigma^{2}\right)$

$\mathrm{Y} \sim \operatorname{Binomial}\left(1, \pi_{x}\right)$ where $\pi_{x}=\mathrm{P}(\mathrm{Y}=1)$

$\pi_{x}=\beta_{0}+\beta_{1} x$

$\mu_{x}=\beta_{0}+\beta_{1} x$

Nevertheless, the values of the odds range from 0 to $\infty$. This odd range makes it not compatible for use for a typical regression analysis, which ranges from $-\infty$ to $+\infty$. To improve on the binary model fitting, a log transformation is required resulting in the naming logit regression (Eqs. 5 and 6)

$\eta_{x}=\log \frac{\pi_{x}}{1-\pi_{x}}$ 
Table 1

Univariate statistics of Zone of Inhibition (ZOI) of different antiseptic measured in $\mathrm{mm}$.

\begin{tabular}{llllll}
\hline & Ivy $(\mathrm{mm})$ & Dettol $(\mathrm{mm})$ & Septol $(\mathrm{mm})$ & Izal $(\mathrm{mm})$ & Control (mm) \\
\hline Bacillus & 20 & 25 & 22 & 12 & 20 \\
E. coli & 27 & 30 & 26 & 13 & 20 \\
Kleb & 18 & 36 & 21 & 15 & 20 \\
Mean & 21.66667 & 30.33333 & 23 & 13.33333 & 20 \\
Median & 20 & 30 & 22 & 12 & 20 \\
SD & 4.725816 & 5.507571 & 2.645751 & 1.527525 & - \\
$p$-value & 0.0138 & 0.0108 & 0.0030 & 0.0060 & \\
& & & & &
\end{tabular}

$\pi_{x}=\frac{e^{\eta_{x}}}{1+e^{\eta_{x}}}$

Where $1-\pi_{x}=\mathrm{P}(\mathrm{Y}=0)$

Therefore, in this study, multivariate Logistic regression analysis was performed to determine the general performance and fitting of different disinfectants against bacteria presence, considering all other variables measured.

\section{Results and discussion}

The result section gives an overview of the efficacy of disinfectants and brand reputation on bathing water quality improvement, and the result of the tests carried out in this regard as per Tables 1-6. The result from the logit regression is in Table 7.

A paired $t$-test conducted with the ZOI obtained for different antiseptic on selected bacteria shown in Table 1 . The test revealed a significant difference in the performance of the various disinfectants on the bacteria. The disinfectants exhibited enough potency for bacteria destruction with Dettol having the highest ZOI with a mean of $30 \mathrm{~mm}$, while Izal had the least ZOI with a mean of $13 \mathrm{~mm}$. The variation in disinfectant performance can be attributed to the difference in the penetration strength of the disinfectants because of the active ingredients present in the disinfectants (Table 1).

*NS implies Not Specified

For this study, the bacteria count (BC) measured after the addition of the various antiseptic were recorded and tabulated. The Shapiro -Wilk test for normality revealed that $\mathrm{BC}$ was not normally distributed with $p<0.05 i$. e. $p=0.000$. The reason behind this was due to the variability in the performance of different antiseptic used in this study. Also, to further analyze the gross performance of these antiseptic, the $\mathrm{BC}$ values obtained during the experimental process were dichotomized into no bacteria and bacteria groups. The reason for this separation was our expectation or hypothesis that there should be no bacteria count present in bathing water after adding these antiseptics. The Wilcoxon's rank-sum test (Mann Whitney U test) was conducted to compare the categorized BC values (Table 2). It showed that $34.4 \%$ (99) of the samples had no bacteria, while $65.6 \%$ (189) had bacteria after $1 \mathrm{~h}$ with a $p$-value of 0.00 . Hence the number of samples with bacteria was significantly higher than the number without bacteria. Accordingly, the disinfectants were not able to destroy the bacteria even after one hour of exposure. The performance of the individual disinfectants on the bacteria was further explored, as shown in Table 3.
Table 3

Performance of different disinfectants on monitored bacteria in water.

\begin{tabular}{|c|c|c|c|c|}
\hline \multirow[t]{2}{*}{ Characteristics } & & \multicolumn{2}{|l|}{ Bacteria groups } & \multirow[t]{2}{*}{${ }^{*} p$-values } \\
\hline & & No bacteria & Bacteria & \\
\hline \multirow{5}{*}{$\begin{array}{l}\text { Disinfectant } \\
\text { Ivy }\end{array}$} & Bacteria type & $\mathrm{N}=29(40 \%)$ & $\mathrm{N}=43(60 \%)$ & \\
\hline & E. coli & $11(45.83)$ & 13(51.47) & 0.668 \\
\hline & Kleb & $8(33.33)$ & $16(66.67)$ & \\
\hline & Bacillus & $10(41.67)$ & $14(58.33)$ & \\
\hline & & $\mathrm{N}=10(14 \%)$ & $\mathrm{N}=62(86 \%)$ & \\
\hline \multirow[t]{4}{*}{ Dettol } & E. coli & $2(8.33)$ & $22(91.67)$ & 0.444 \\
\hline & Kleb & $5(20.83)$ & $19(71.97)$ & \\
\hline & Bacillus & $3(12.50)$ & $21(87.50)$ & \\
\hline & & $\mathrm{N}=20(28 \%)$ & $\mathrm{N}=52(72 \%)$ & \\
\hline \multirow[t]{4}{*}{ Izal } & E. coli & $0(0.00)$ & $24(100)$ & 0.000 \\
\hline & Kleb & $20(83.33)$ & $4(16.67)$ & \\
\hline & Bacillus & $0(0.00)$ & $24(100)$ & \\
\hline & & $\mathrm{N}=40(56 \%)$ & $\mathrm{N}=32(44 \%)$ & \\
\hline \multirow[t]{3}{*}{ Septol } & E. coli & $21(87.50)$ & $3(12.50)$ & 0.000 \\
\hline & Kleb & 19(79.17) & $5(20.83)$ & \\
\hline & Bacillus & $0(0.00)$ & $24(100)$ & \\
\hline
\end{tabular}

Table 4

Monitoring disinfectants performance at different dosage.

\begin{tabular}{|c|c|c|c|c|}
\hline \multirow[t]{2}{*}{ Characteristics } & & \multicolumn{2}{|l|}{ Bacteria groups } & \multirow[t]{2}{*}{${ }^{*} p$-values } \\
\hline & & No bacteria & Bacteria & \\
\hline Disinfectant & Dosage (ml) & $\mathrm{N}=29(40 \%)$ & $\mathrm{N}=43(60 \%)$ & \\
\hline \multirow[t]{5}{*}{ Ivy } & 0.4 & $8(44.40)$ & $10(56.60)$ & \multirow{5}{*}{0.888} \\
\hline & 0.8 & $7(38.89)$ & $11(61.11)$ & \\
\hline & 1.2 & $6(33.33)$ & $12(66.67)$ & \\
\hline & 1.6 & $8(44.44)$ & $10(56.56)$ & \\
\hline & & $\mathrm{N}=10(14 \%)$ & $N=62(86 \%)$ & \\
\hline \multirow[t]{5}{*}{ Dettol } & 0.4 & $1(5.56)$ & $17(94.44)$ & \multirow[t]{5}{*}{0.006} \\
\hline & 0.8 & $1(5.56)$ & $17(94.44)$ & \\
\hline & 1.2 & $1(5.56)$ & $17(94.44)$ & \\
\hline & 1.6 & $7(38.89)$ & $11(61.11)$ & \\
\hline & & $\mathrm{N}=20(28 \%)$ & $\mathrm{N}=52(72 \%)$ & \\
\hline \multirow[t]{5}{*}{ Izal } & 0.4 & $4(22.22)$ & $14(77.78)$ & \multirow[t]{5}{*}{0.775} \\
\hline & 0.8 & $4(22.22)$ & $14(77.78)$ & \\
\hline & 1.2 & $6(33.33)$ & $12(66.67)$ & \\
\hline & 1.6 & $6(33.33)$ & $12(66.67)$ & \\
\hline & & $\mathrm{N}=40(56 \%)$ & $N=32(44 \%)$ & \\
\hline \multirow[t]{4}{*}{ Septol } & 0.4 & $10(55.56)$ & $8(44.44)$ & \multirow[t]{4}{*}{0.930} \\
\hline & 0.8 & $9(50.00)$ & $9(50.00)$ & \\
\hline & 1.2 & $11(61.11)$ & $7(38.89)$ & \\
\hline & 1.6 & $10(55.56)$ & $8(44.44)$ & \\
\hline
\end{tabular}

\subsection{Brand performance on different bacteria}

Table 3 clearly showed no significant difference in the performance of Ivy ( $p=0.668)$ concerning the three bacteria, namely: Bacillus spp., Klebsiella spp., and E. coli. Same goes for Dettol $(p=0.444)$. However, Izal and Septol exhibited a significant difference in performance concerning the three organisms. It was found that though both Dettol and Ivy, Klebsiella spp. was most resistant to Ivy, while Bacillus spp. was most

Table 2

Two-sample Wilcoxon rank-sum (Mann-Whitney) test.

\begin{tabular}{|c|c|c|c|c|c|}
\hline Bacteria Count & Observed & Rank sum & Expected & $\mathrm{Z}$ & Prob $>\mid z$ \\
\hline No bacteria present $(<0$ CFU $/ 100 \mathrm{~mL})$ & 99 & 4999.5 & 14305.5 & -14.164 & 0.0000 \\
\hline Bacteria present $(>0 \mathrm{CFU} / 100 \mathrm{~mL})$ & 189 & 36616.5 & 27310.5 & & \\
\hline
\end{tabular}


Table 5

Disinfectant performance at different exposure times.

\begin{tabular}{|c|c|c|c|c|}
\hline \multicolumn{2}{|c|}{ Characteristics } & \multicolumn{2}{|c|}{ Bacteria groups } & \multirow[t]{2}{*}{${ }^{*} p$-values } \\
\hline & & No bacteria & Bacteria & \\
\hline Disinfectant & $\begin{array}{l}\text { Time (mins): } \\
\text { frequency }(\%)\end{array}$ & $\begin{array}{l}\mathrm{N}=29(40 \\
\%)\end{array}$ & $\begin{array}{l}\mathrm{N}=43(60 \\
\%)\end{array}$ & \\
\hline \multirow[t]{7}{*}{ Ivy } & 0 & $3(25.00)$ & $9(75.00)$ & 0.011 \\
\hline & 5 & $2(16.67)$ & $10(83.33)$ & \\
\hline & 10 & $4(33.33)$ & $8(66.67)$ & \\
\hline & 15 & $3(25.00)$ & $9(75.00)$ & \\
\hline & 30 & $8(66.67)$ & $4(33.33)$ & \\
\hline & 60 & $9(75.00)$ & $3(25.00)$ & \\
\hline & & $\begin{array}{l}\mathrm{N}=10(14 \\
\%)\end{array}$ & $\begin{array}{l}\mathrm{N}=62(86 \\
\%)\end{array}$ & \\
\hline \multirow[t]{7}{*}{ Dettol } & 0 & $3(25.00)$ & $9(75.00)$ & 0.803 \\
\hline & 5 & $1(8.33)$ & 11(91.67) & \\
\hline & 10 & $1(8.33)$ & $11(91.67)$ & \\
\hline & 15 & $1(8.33)$ & $11(91.67)$ & \\
\hline & 30 & $2(16.67)$ & $10(83.33)$ & \\
\hline & 60 & $2(16.67)$ & $10(83.33)$ & \\
\hline & & $\begin{array}{l}\mathrm{N}=20(28 \\
\%)\end{array}$ & $\begin{array}{l}\mathrm{N}=52(72 \\
\%)\end{array}$ & \\
\hline \multirow[t]{8}{*}{ Izal } & 0 & $2(16.67)$ & $10(83.33)$ & 0.819 \\
\hline & 5 & $2(16.67)$ & $10(83.33)$ & \\
\hline & 10 & $4(33.33)$ & $8(66.67)$ & \\
\hline & 15 & $4(33.33)$ & $8(66.67)$ & \\
\hline & 30 & $4(33.33)$ & $8(66.67)$ & \\
\hline & 60 & $4(33.33)$ & $8(66.67)$ & \\
\hline & & $\mathrm{N}=40$ & $N=32$ & \\
\hline & & $\%)$ & $\%)$ & \\
\hline \multirow[t]{6}{*}{ Septol } & 0 & $3(25.00)$ & $9(75.55)$ & 0.258 \\
\hline & 5 & $7(58.33)$ & $5(41.67)$ & \\
\hline & 10 & $8(66.67)$ & $4(33.33)$ & \\
\hline & 15 & $6(50.00)$ & $6(50.00)$ & \\
\hline & 30 & $8(66.67)$ & $4(33.33)$ & \\
\hline & 60 & $8(66.67)$ & $4(33.33)$ & \\
\hline
\end{tabular}

Table 6

Disinfectants efficacies at different stratified time assumed to be bathing wait times.

\begin{tabular}{|c|c|c|c|c|}
\hline \multicolumn{2}{|l|}{ Characteristics } & \multicolumn{2}{|c|}{ Bacteria groups } & \multirow[t]{2}{*}{${ }^{*} p$-values } \\
\hline & & No bacteria & Bacteria & \\
\hline Disinfectant & $\begin{array}{l}\text { Time (mins): } \\
\text { frequency }(\%)\end{array}$ & $\begin{array}{l}\mathrm{N}=29(40 \\
\%)\end{array}$ & $\begin{array}{l}\mathrm{N}=43(60 \\
\%)\end{array}$ & \\
\hline Ivy & $\begin{array}{l}<10 \\
=10 \\
>10\end{array}$ & $\begin{array}{l}5(20.83) \\
4(33.33) \\
20(55.56) \\
N=10(14 \\
\%)\end{array}$ & $\begin{array}{l}19(71.97) \\
8(66.67) \\
16(44.44) \\
\mathrm{N}=62(86 \\
\%)\end{array}$ & 0.023 \\
\hline Dettol & $\begin{array}{l}<10 \\
=10 \\
>10\end{array}$ & $\begin{array}{l}4(16.67) \\
1(8.33) \\
5(13.89) \\
N=20(28 \\
\%)\end{array}$ & $\begin{array}{l}20(83.33) \\
11(91.67) \\
31(86.11) \\
N=52(72 \\
\%)\end{array}$ & 0.793 \\
\hline Izal & $\begin{array}{l}<10 \\
=10 \\
>10\end{array}$ & $\begin{array}{l}4(16.67) \\
4(33.33) \\
12(33.33) \\
N=40(56 \\
\%)\end{array}$ & $\begin{array}{l}20(83.33) \\
8(66.67) \\
24(66.67) \\
N=32(44 \\
\%)\end{array}$ & 0.330 \\
\hline Septol & $\begin{array}{l}<10 \\
=10 \\
>10\end{array}$ & $\begin{array}{l}10(41.67) \\
8(66.67) \\
22(61.11)\end{array}$ & $\begin{array}{l}14(58.33) \\
4(33.33) \\
14(38.89)\end{array}$ & 0.232 \\
\hline
\end{tabular}

resistant to Dettol. Dettol appeared to be the least efficient of the four disinfectants with an average performance of $14 \%$. Septol was the most productive with an average performance of $56 \%$, followed by Ivy and Izal, with an average performance of $40 \%$ and $28 \%$, respectively. The performance was computed as the percentage of samples with no bacteria after one hour of contact with the disinfectants. Septol successfully destroyed all the Klebsiella spp. in $87.5 \%$ of the samples and all the Klebsiella spp. in $79.2 \%$ of the water samples after one hour of contact but appeared to have little or no effect on Bacillus spp.. Izal appeared to have little or no effect on E.coli and Bacillus spp. but appeared particularly potent against Klebsiella spp..The overall performance of Septol solution reveals a great statistically significant difference in the relative performance in the removal of the organisms if present in bathing water $\left(x^{2}=55.3846 ; p=0.000\right)$.

\subsubsection{Effect of dosage}

Table 4 summarizes the performance of the various disinfectants for dosage. For Ivy, it revealed that when $0.4 \mathrm{~mL}, 0.8 \mathrm{~mL}, 1.2 \mathrm{~mL}$, and 1.6 $\mathrm{mL}$ were added, eight samples (44.40\%) out of eighteen samples were free from the presence of bacteria, seven samples (38.89\%), six samples (33.33\%) and eight samples (44.44\%) all out of 18 samples had no bacteria in them respectively (mean $=210 \mathrm{CFU} / 100 \mathrm{~mL}$ ). Table V shows that increasing the dosage of disinfectant even by four factors did not result in any significant increase in efficacy of the disinfectants, except for Dettol. Izal manifested a slight but not significant increase in efficiency while the performance of Ivy and Septol was unaffected by increased dosage.

The effectiveness of Dettol in destroying bacteria in water was assessed using Pearson's chi-square value, which showed a massive statistically significant difference between the two categories $\left(x^{2}=12.5419 ; p=0.006\right)$. Izal was able to disinfect only $22 \%$ of the water samples at a dosage of $0.4 \mathrm{~mL}$ while increasing the dosage to 1.6 $\mathrm{mL}$ (i.e., a fourfold increase) achieved total disinfection of $33.3 \%$ of the water samples. Septol achieved full disinfection of more than $50 \%$ of the samples at all dosages. Specifically, it revealed that ten samples $(55.56 \%)$ out of eighteen samples were disinfected when $0.4 \mathrm{~mL}$. Increasing the dosage to $1.6 \mathrm{~mL}$ (i.e., a fourfold increase) did not improve disinfection efficiency. The overall performance between the two bacterial categories revealed no statistically significant difference between samples, even though its performance was commendable $\left(x^{2}=0.4500 ; p=0.930\right)$.

\subsubsection{Effect of exposure duration of disinfectants on bacteria}

Table 5 reveals the exposure duration of the various disinfectants on bacteria count. It was found that all four disinfectants can achieve higher efficiency of disinfection at a prolonged contact time. For Ivy, Dettol, Izal, and Septol, the disinfection efficiency increased from $16 \%$ to $75 \%, 8.33 \%-16.67 \%, 16.67 \%-33.33 \%$, and $58.33 \%-66.67 \%$ respectively as contact time increased to one hour. However, only Ivy exhibited a significant increase in performance with an increase in contact time. This suggests that the best performance of this antiseptic is obtained at a prolonged duration, which is practically not achievable in most cases. Therefore, the above observation runs contrary to the usual practice of using bathwater almost immediately after adding a disinfectant. The performance of Dettol did not improve significantly even after a prolonged contact time was allowed. The performance of Dettol increased from $16.67 \%$ after a contact time of 5 min to $33.3 \%$ after one hour. This increase was found not to be statistically significant, and hence, the $16.7 \%$ increase in efficiency does not justify the $1100 \%$ increase in contact time.

The result obtained with Izal antiseptic at different times showed a similar trend with Dettol but slightly better. Specifically, it revealed that the same number of samples $(2,16.67 \%)$, having no bacteria and 4 $(33.33 \%)$ in the water samples at $0,5,10,15,30$, and $60 \mathrm{~min}$ respectively. Additionally, the general performance of this antiseptic across subsets of different categories shows no statistically significant 
Table 7

Modelling disinfectants performance on bacteria.

\begin{tabular}{|c|c|c|c|c|c|c|c|c|}
\hline \multirow[t]{2}{*}{ Variables } & \multicolumn{2}{|l|}{ IZAL } & \multicolumn{2}{|l|}{ SEPTOL } & \multicolumn{2}{|l|}{ DETTOL } & \multicolumn{2}{|l|}{ IVY } \\
\hline & B & Significance & B & Significance & B & Significance & B & Sig \\
\hline Dosage & -38.483 & .986 & -.173 & .853 & -2.628 & .013 & -.138 & .814 \\
\hline Duration & -3.079 & .986 & -.123 & .045 & -.003 & .855 & -.044 & .002 \\
\hline E. coli & & 1.000 & & .489 & & .417 & & .451 \\
\hline Kleb & .000 & 1.000 & -27.093 & .997 & .498 & .622 & -.396 & .530 \\
\hline Bacillus & -217.874 & .986 & -26.070 & .997 & -.709 & .409 & .427 & .516 \\
\hline constant & 263.360 & .986 & 26.551 & .997 & 5.113 & .001 & 1.358 & .088 \\
\hline Cox \& Snell $\mathrm{R}^{2}$ & 0.677 & & 0.588 & & 0.131 & & 0.165 & \\
\hline Nagelkerke $\mathrm{R}^{2}$ & 0.976 & & 0.786 & & 0.237 & & 0.222 & \\
\hline Correct prediction for no bacteria (\%) & 98.6 & & 94.9 & & 0 & & 43.3 & \\
\hline Correct prediction for presence of bacteria (\%) & 98.1 & & 78.8 & & 100 & & 83.3 & \\
\hline Chi-square & 81.626 & & 63.83 & & 10.121 & & 7.93 & \\
\hline Significance & 0 & & 0 & & 0.038 & & 0.44 & \\
\hline
\end{tabular}

difference $\left(x^{2}=2,2154 ; p=0.819\right)$. Though the overall performance indicated no statistically significant difference $\left(x^{2}=6.250 ; p=0.258\right)$, there was a general increase in performance with contact time. However, this implied that more time would be required for the better performance of the disinfectants. However, one is not expected to wait indefinitely for the disinfectants to reach maximum efficiency. Hence, the contact time was stratified into three main groups: $<10 \mathrm{~min},=10$ min, and $>10 \mathrm{~min}$. Table 6 showed that for Ivy and Septol, far better performance of the disinfectants was achieved when the contact time was longer than $10 \mathrm{~min}$.

\subsubsection{Modelling brand efficacy on bacteria using logit regression}

A binary logistic regression model was performed on the experimental data to determine their comparative efficacies on the different bacteria. First, the data were rescaled to make it suitable for logistic regression analysis. All samples that recorded the presence of bacteria were assigned the value of one, while those that did not record any bacteria were assigned a value of zero. A regression logistic regression model was developed for bacteria presence against dosage, duration, and organism type with a cut-off value of a value of 0.5 . The model parameters showed that the disinfectants' higher dosages were more likely to eradicate bacteria in water (Table 7). However, this effect was not significant for all four disinfectants. Only Dettol showed a considerable impact of dosage on bacteria eradication with a parameter significance of 0.013. This result implies that more disinfectant (Dettol) must be applied to the same volume of water compared to others to obtain a significant removal of bacteria, which makes it less appealing for consumers to purchase. Meanwhile, this is not the situation for other disinfectants. For example, Septol disinfectant, which performed better from our study, increasing the dosage will only be a waste and incur more cost for the user as no significant bacteria was noticed ( $p>0.05$ ). Duration of exposure contributed significantly to the models for Ivy and Septol with a significance of 0.002 and 0.045 for the model coefficients, respectively. The models suggest that longer waiting times increased the efficacy of these disinfectants. Organisms type did not contribute significantly to the models irrespective of their overall performance. Overall, the models for Izal and Septol fitted the experimental data well with Nagelkerke $R^{2}$ values of 0.97 and 0.786 , respectively. The model for Izal correctly predicted $98.6 \%$ of total bacteria eradication and 98.1 $\%$ of incomplete elimination while the model for Septol correctly predicted $94.9 \%$ of complete bacteria eradication and $78.8 \%$ of incomplete destruction.

Generally, it is observed that antiseptics' poor performance was recorded from brands of old and preferred reputation (Dettol and Izal).
The reason could be due to the improper usage of the products by consumers, which has led to the resistance of these bacteria to disinfection(Tenebe et al., 2019; Obasuyi et al., 2020). This process has further affected the cresylic and creosote (active agent for Izal) and para-chloro-meta-xylenol (active agent for Dettol) or quick degradation of these active agents when in solution. The focused group discussion conducted revealed that most of the respondents do not adhere to recommended dosages. For instance, while two caps were recommended for Dettol, most respondents admitted to using no more than two caps. Most consumers believed that the two caps recommended were more than what was required. Some perceive it as a market strategy for the brands to continuously sell their products while others do not have enough money to buy these products frequently as they are expensive. Septol was the only antiseptic that satisfied our hypothesis that any antiseptic addition should considerably destroy bacteria in bathing water. The reason for this could be the high motility rate of the active ingredient hexachlorophene (3,4,6-trichlorophenol), which swiftly destroyed the extracellular walls of the bacteria such that re-growth for both E. coli and Klebsiella spp. was impossible. However, it is worth mentioning that among these brands investigated, Dettol antiseptic had an over average consumer preference. This compelling preference is attributed to its long age of existence, beautiful jingles, mild effects the antiseptic gives to the skin, and other undocumented reasons. Izal disinfectant was the least used in homes for bathing water improvement because of the harsh feeling on the skin, toxic smell, and very turbid appearance. In contrast, Septol and Ivy may never be used in the homes of some respondents because they believe those brands are imitators trying to make money for themselves or scarcely used products even when purchased.

\section{Conclusion}

The use of disinfectants is especially crucial for the rural communities who mostly depend on the use of rainwater, hand-dug wells, river, or stream water for bathing, all of which contained sufficient bacteria. However, it is essential to mention that even though the findings from this study is a complete departure from the perception of the public concerning brand performance, it may not be a representative of all the brands found in the market as we present findings from the various antiseptic collected at the time of the experimental investigation. Therefore, this study recommends that the water drawn from a well, reservoir, or tap should be left for not more than five (5) minutes before an antiseptic is added . By so doing, it is expected that the shock experienced by the bacteria would have reduced as well as 
the bacteria commenced in growth. At this time, adding any antiseptic would be worth it. Also, this study suggests there is a need for adequate dilution of skin disinfectants in water $f$ towards achieving effective performance. Better yet, after the application of skin disinfectants in water, the solution should be adequately stirred and not used immediately.

Furthermore, regulatory agencies such as the Standard Organization of Nigeria (SON) should improve their quality assurance for standards to be followed to mitigate brand performance variances between similar products. Manufacturers, in turn, are encouraged to introduce product security measures that would make consumers identify postiche brands. The introduction of such measures will reduce variance in product performance and produce more specific antiseptic that can eliminate bacteria of these types analyzed in this study to improve bathing water quality. Also, we believe that the efficacies of these skin disinfectants should be indicated on the bottles i.e., the extent these antiseptics can function so as not to mislead users with the belief that the consumers would use as prescribed. This will reduce the initial resistance of bacteria to the active ingredient that could result from improper use of these products. As we had in this study were the disinfectant claimed to destroy E. coli, whereas that was not wholly true. More work can are required to verify these findings. At the same time, an extension of this study should include the performance of both skin and non-skin disinfectant performance in the presence of hardness and turbidity in water.

\section{Author Statement}

I.T Tenebe: conceived, generated data from the laboratory, and wrote the first draft of manuscript. Also analyzed the data

C.C.Nnaji: conceived and revised manuscript before submission. Also added to the analyses

C.P. Emenike: added to the manuscript and generated the data

B.U Ngene: revised manuscript and generated data.

\section{Declaration of Competing Interest}

The authors of this manuscript received no funding and there is no conflict of interest regarding the paper submission of any kind and we hope the manuscript will be favorably accepted for peer review.

\section{Acknowledgment}

We also thank the reviewers for their contributions to the content of the manuscript.

\section{References}

Agunwamba, J.C., Tenebe, I.T., Emenike, C.P., 2013. Effect of disinfectants on aerobic sewage degradation using dettol and Izal as case study. Int. J. Struct. Civil Engg. Res. 2 (4) 184-184.

Ahmed, W., Vieritz, A., Goonetilleke, I.A., Gardner, T., 2010. Health risk from the use of roof-harvested rainwater in Southeast Queensland, Australia, as potable or nonpotable water, determined using quantitative microbial risk assessment. Appl. Environ. Microbiol. 7382-7391. https://doi.org/10.1128/AEM.00944-10.

Ali, J., Ali, Jamil N., Waseem, H., Khan, K., Pan, G., 2017. Insight into eco-friendly fabrication of silver nanoparticles by Pseudomonas aeruginosa and its potential impacts. J. Environ. Chem. Eng. 5, 3266-3272.

Alkolaibe, A.M., Al-Ameri, G.A., Alkadasi, M.N., Zaid, A.A., 2015. Study of the efficacy of disinfectants against bacteril contamination in burns unit-algumhory and International Yemen hospitals in Taiz city. Int. J. Res. Studies Biosci. 3 (3), 26-33.

Chubaka, C.E., Whiley, H., Edwards, J.W., Ross, K.E., 2018. Microbiological values of rainwater harvested in Adelaide. Pathogens 2018 (7), 21. https://doi.org/10.3390/ pathogens7010021.

Coleman, B.L., Louie, M., Salvadori, M.I., McEwen, S.A., Neumann, N., Sibley, K., Irwin, R.J., Jamieson, F.B., Daignault, D., Majury, A., 2013. Contamination of Canadian private drinking water sources with antimicrobial resistant Escherichia coli. Water Res. 47, 3026-3036.

Cui, Q., Fang, T., Huang, Y., Dong, P., Wang, H., 2017. Evaluation of bacterial pathogen diversity, abundance and health risks in urban recreational water by amplicon nextgeneration sequencing and quantitative PCR. J. Environ. Sci.

El-Mahmood, A.M., Doughari, J.H., 2009. Bacteriological examination of some diluted disinfectants routinely used in the Specialist Hospital Yola, Nigeria. African J. Pharm. Pharmacol. 3 (5), 185-190.

Emenike, C.P., Tenebe, I.T., Omole, D.O., Ngene, B.U., Oniemayin, B.I., Maxwell, O., Onoka, B.I., 2017. Accessing safe drinking water in sub-Saharan Africa: issues and challenges in South-west Nigeria. Sustain. Cities Soc. 30, 263-272. https://doi.org/ $10.1016 /$ j.scs.

Farzana, K., Batool, S., Ismail, T., Asad, M.H., Rasool, F., Khiljee, S., Murtaza, G., 2011. Comparative bactericidal activity of various soaps against gram-positive and gramnegative bacteria. Scientific Res. Essays 6 (16), 3514-3518.

Gupta, J., Vegelin, C., 2016. Sustainable development goals and inclusive development. Int Environ Agree: Polit Law Econ. 16 (3), 433-448. https://doi.org/10.1007/ s10784-016-9323-z.

Khan, K., Lu, Y., Saeed, M.A., Bilal, H., Sher, H., Khan, H., Ali, J., Wang, P., Uwizeyimana, H., Baninla, Y., Li, Q., Liu, Z., Nawab, J., Zhou, Y., Su, C., Liang, R., 2017. Prevalent fecal contamination in drinking water resources and potential health risks in Swat, Pakistan. J. Environ. Sci. https://doi.org/10.1016/j.jes.2017.12.008.

Montgomery, D.C., Peck, E.A., Vining, G.G., 2012. Introduction to Linear Regression Analysis Vol. 821 John Wiley \& Sons.

Obasuyi, O., McClure, J., Oronsaye E, F., Akerele O, J., Conly, J., Zhang, K., 2020. Molecular Characterization and Pathogenicity of Staphylococcus aureus Isolated from Benin-City, Nigeria. microoganisms 8 (6). https://doi.org/10.3390/ microorganisms 8060912.

Okore, C.C., Mbanefo, O.N., Onyekwere, B.C., Onyewenjo, S.C., Ozurumba, A.U., AbbaFather, C.A.M., 2014. Antimicrobial efficacy of selected disinfectants. Am. J. Biol. Life Sci. 2 (2), 53-57 2014.

Olowe, O.A., Olayemi, A.B., Eniola, K.I.T., Adeyeba, O.A., 2004. Antibacterial activity of some selected disinfectants regularly used in hospitals. African J. Clinical Experiment. Microbiol. 5 (1), 126-130 ISSN 1595-1689X, AJCEM/2002111/2412, 2004.

Omole, D.O., Ndambuki, J.M., 2014. Sustainable living in Africa: case of water, sanitation, air pollution and energy. Sustainability 6 (8), 5187-5202.

Palaniappan, M., Gleick, P.H., Allen, L., Cohen, M.J., Christian-Smith, J., Smith, C., 2010. Clearing the Waters; A Focus on Water Quality Solutions. [Retrieved07:09:2015 at http://www.unep.org/PDF/Clearing the Waters.pdf].

Reichel, M., Schlicht, A., Ostermeyer, C., Kampf, G., 2014. Efficacy of surface disinfectant cleaners against emerging highly resistant gram-negative bacteria. BMC Infect. Dis. 14 (292).

Riaz, S., Ahmad, A., Hasnain, S., 2009. Antibacterial activity of soaps against daily encountered bacteria. Afr. J. Biotechnol. 8 (8), 1431-1436.

Russell, A.D., 1996. Activity of biocides against mycobacteria. J. Appl. Bacteriol. 81, 87S-101S.

Saha, A.K., Haque, M.F., Karmaker, S., Mohanta, M.K., 2009. Antibacterial effects of some antiseptics and disinfectants. J. Life Earth Sci. (3-4), 19-21.

Tenebe T, I., Emenike C, P., Ogarekpe M, N., Taiwo S, O., 2019. Preliminary assessment of the suitability of commonly used antiseptics in the elimination of bacteria in bathing water. Environmental Monitoring and Assessment 370 (191). https://doi.org/10. 1007/s10661-019-7442-z.

Tenebe, I.T., Ogbiye, A.S., Omole, D.O., Emenike, C.P., 2016. Estimation of longitudinal dispersion co-efficient: a review. Cogent Eng 3 (1), 216-244. https://doi.org/10. $1080 / 23311916.2016 .1216244$.

Tytler, B.A., Adeyemi, O.J., Adetoran, E.O., Biyama, H.M., 2006. Microbial contamination of disinfectant solutions in some health care institutions of three towns in Northern Nigeria. J. Pharm. Biores. 3 (2), 77-82.

Vestby, L.K., Nesse, L.L., 2015. Wound care antiseptics - performance differences against Staphylococcus aureus in biofilm. Acta Vet. Scand. 57, 22. 